\section{Triggers for treaty negotiations: could lessons from environmental protection inform a prospective pandemic treaty?}

The factors in favour of starting negotiations on a pandemics treaty are similar to those that triggered the successful negotiation of key environmental agreements, Katharina Kummer Peiry reports

\section{Katharina Kummer Peiry}

In March 2021, 26 heads of state called for a global pandemics treaty, illustrating the magnitude of the threat. ${ }^{1}$ Not surprisingly, the call has prompted reports and recommendations from specialist bodies as well as lively discussion in international public health policy. Is a treaty the answer? If so, is the time right?

When faced with questions of this nature, lawyers and policy makers like to turn to precedents. We argue that, although treaty making experience in health has so far been limited, other fields, particularly the closely related field of environmental protection, might point to solutions and help avoid mistakes. We also argue that the triggers for treaty negotiations may be similar for a pandemic treaty.

Looking at environmental treaty negotiations is interesting because they were preceded by controversies and uncertainties similar to those now faced by public health policy. Which factors eventually led to the decision to negotiate a treaty? Who took the initiative? And what made the negotiations successful?

\section{What triggered the decision to negotiate a treaty?}

\section{Threat of a catastrophe}

To date, there has not been a global environmental menace that has hit the entire planet as suddenly and dramatically as the covid-19 pandemic. Climate change and the depletion of the stratospheric ozone layer, while threatening life on earth, materialised progressively over many years and were not widely recognised for several decades. Nevertheless, each of these phenomena eventually triggered the negotiation of a treaty regime.

The menace of damage that did not threaten the planet as a whole has also triggered environmental treaty negotiations. Discovery of the devastating effects of methyl mercury on brain development led to negotiation of the 2013 Minamata Convention on Mercury. The 2001 Stockholm Convention on Persistent Organic Pollutants was negotiated as it became known that these substances cause malformations in embryos of animals and humans. Pollution of the oceans, caused by the widespread practice of discharging chemicals and wastes from ships until the 1970s, triggered the negotiation of a treaty regime with progressively more stringent measures. ${ }^{23}$

\section{Results of scientific research}

Science has been a common trigger for environmental treaty negotiations. Unlike the covid-19 pandemic, most environmental damage was not initially evident to non-specialists. Willingness to engage in treaty negotiations was often dependent, therefore, on scientific evidence of damage. In some areas, it took by the scientific community, and yet more time for acceptance by the policy world. For example, although climate change attracted scientific interest from the late 196os onwards, treaty negotiations only began in 1991, following a series of international scientific and policy gatherings in the late 1970 s and 1980 s, and based on the first assessment report of the Intergovernmental Panel on Climate Change (IPCC) in 1990.4 The science continued to be questioned, but has, over the past 20 years, been confirmed by the successive reports of the IPCC, which is recognised today as the key scientific body on the subject. Recent IPCC reports have been crucial in the negotiation of the Paris Agreement.

By contrast, the Cartagena Protocol on Biosafety is an example of an environmental treaty negotiated despite the absence of scientific evidence of damage. The negotiations were triggered by concerns regarding genetically modified organisms, and more specifically the opposition of developing countries to becoming a testing ground for potentially unsafe technology. ${ }^{5}$

\section{Internationally publicised scandals}

In some cases, incidents causing environmental damage attracted attention from the media and non-governmental organisations, which in turn triggered treaty negotiations. An example is the Basel Convention, ${ }^{6}$ negotiated in response to media reports on the dumping of toxic wastes from the industrialised world in developing countries in the 1980s. Environmental pressure groups coined terms such as "waste colonialism" and "toxic terrorism," accusing industrialised states of using poorer countries as a cheap dumping ground. ${ }^{7}$

\section{A step-wise approach}

The need for codifying measures and obligations to states was not always immediately recognised. Accordingly, a generally worded treaty constituting a framework for cooperation but containing no concrete measures was initially negotiated in some areas. Increasing consensus subsequently allowed many years for research to yield results recognised 
for agreement on substantive obligations, in some cases followed by progressively more stringent measures. An example is the negotiation of the climate treaty system, starting with the generally worded UN Framework Convention on Climate Change in 1991 and culminating in the 2015 Paris Agreement, which features concrete obligations for all states. The same approach was taken regarding ozone depleting substances, with the initial adoption of a treaty setting out a framework for cooperation followed by a substantive protocol, which was then regularly amended to include ever more stringent measures. ${ }^{8}$

Where agreement on treaty negotiations was initially lacking, non-binding instruments to support national action were sometimes adopted, later followed by a treaty. For example, the guidelines adopted by the Food and Agriculture Organization of the United Nations ${ }^{9}$ and the United Nations Environment Programme ${ }^{10}$ to assist countries in the management of chemicals in international trade provided the basis for the negotiation of the Rotterdam Convention ${ }^{11}$ 10 years later. The Cartagena and Nagoya Protocol ${ }^{12}$ negotiations were initiated because developing countries found the original non-binding guidelines insufficient.

\section{Who initiated the negotiations?}

\section{A particularly committed country}

Negotiation of some environmental treaties was proposed to the relevant United Nations organisation by one of its member states. The initiating country sometimes sought co-sponsorship from other states from different regions to broaden political support. For example, Switzerland initiated the negotiation of the Basel Convention jointly with Hungary and Senegal, and subsequently provided funding for the negotiation process. Brazil spearheaded the negotiations on the Nagoya Protocol and Ethiopia those on the Cartagena Protocol.

\section{A global non-UN organisation}

The International Union for the Conservation of Nature (IUCN), a unique organisation with universally recognised expertise in wildlife and nature protection, played a key role in the negotiation of global treaties in this field. An IUCN assembly resolution in the early $1960 \mathrm{~s}$ called for a treaty on the trade in endangered species, eventually resulting in the negotiation of the Convention on International Trade in Endangered Species of Wild Fauna and Flora. ${ }^{13} 14$ In the 1980 , IUCN recommended the elaboration of a treaty to protect biological diversity, which later provided a basis for the negotiation of the Convention on Biological Diversity. ${ }^{15}$

\section{Committed individuals}

The discussions that led to the adoption of the Ramsar Convention on Wetlands ${ }^{16}$ were initiated in the 1960 s by a few committed leaders of non-governmental organisations with high standing in the international nature protection community, who obtained the support of their membership. ${ }^{17}$ Individual civil servants in some cases acted as the masterminds behind their countries' proposal of treaty negotiations.

\section{What made treaty negotiations successful?}

\section{Broad understanding of the problem}

Where the environmental problem under discussion was easily understandable, not only by specialists but also by the general public, and easy to relate to emotionally, agreement on measures to tackle it was more easily achieved. An example is the increased incidence of skin cancer because of ozone depletion, which led to support for the negotiation of the ozone treaties.
When countries usually opposed to international measures are affected

Where the environmental problem also affected industrialised countries, including the most powerful among them, it was easier to move the discussion forward. For example, in the negotiation of the ozone treaties, the US advocated strong measures, and subsequently became a party to the treaties.

\section{Availability of technical solutions}

Where technology was available or could be developed by industry with financial gain, agreement on a treaty was more easily achieved. For example, during negotiations on the successive amendments to the Montreal Protocol, substitutes for chlorofluorocarbons became available.

\section{Favourable national legislation}

Countries that enacted national legislation introducing environmental measures have been known to push for the same measures at international level so as not to expose their industries to commercial disadvantage. For example, in the negotiations on the Cartagena Protocol, EU member states supported prohibition of international trade in genetically modified organisms after EU legislation banned their use.

\section{Financial support for developing countries through an international financial mechanism}

Where a financial mechanism to support developing countries in the implementation of a treaty existed or was established during the negotiations, support by this group of countries was more readily forthcoming. Examples include the Multilateral Fund of the ozone treaties and the Global Environment Facility, designated as the financial mechanism to key environmental treaties, including the UN Convention to Combat Desertification.

\section{What were the obstacles?}

Conversely, opposition by a powerful group of countries, scientific uncertainty, environmental damage occurring predominantly in less powerful countries, and high costs, as well as negative economic or trade impacts of potential measures have been known to delay environmental treaty negotiations, for example on the Cartagena Protocol. In some areas, for example marine pollution from land based sources and protection and management of forests, treaty negotiations were not initiated because of such obstacles. Conversely, many international environmental treaties that are successful today have at some stage faced collapse of negotiations, the latest example being the Paris Agreement.

\section{What else should be taken into account?}

Environmental treaties also have substantive relevance for a pandemics treaty. Dealing with pandemics is multifaceted and multisectoral. Accordingly, some areas that require global norms under a pandemic treaty are partially covered by existing treaties in other fields such as trade, environment, disaster response, and human rights. This requires carefully crafted synergy with-and adaptation to-said treaties, which have been ratified by all or most member states of the World Health Organization. A key

environmental treaty tackling matters that a pandemic treaty should also cover is the Convention on Biological Diversity and its Nagoya Protocol on access and benefit sharing. The conventions on wildlife trade and desertification ${ }^{18}$ should also be considered when drafting the treaty's pandemic prevention provisions in line with the One Health approach, something expected by most countries. 
Other environmental regimes, including in the areas of climate change and chemical and nuclear safety, may need to be consulted. This would be in line with the close links between environmental factors and health in general ${ }^{19}$ and health emergencies in particular. It would also be in line with the proposed multisectoral character of the treaty, expected to embrace factors from health system capacities, vaccines, and other essential products to sharing of information and technologies, equity, and One Health, among others, with a whole-of-government and whole-of-society approach in preventing and confronting future pandemics.

\section{Conclusion}

This brief overview shows that the many factors that have triggered environmental treaty negotiations are also currently present in pandemic preparedness and response. Indeed, in no area of environmental protection has the need for international cooperation seemed as obvious and immediate as with regards to pandemics such as covid-19-after nearly two years, nobody can seriously doubt the global menace of pandemics, or the underlying science. The current pandemic has also produced its share of internationally publicised scandals, notably those related to the uneven distribution of vaccines between affluent and under-resourced countries. The need to correct this provides a strong incentive for negotiating a pandemics treaty. With the urgent call for a treaty by a group of heads of state, subsequently supported by specialist bodies, negotiation of a pandemic treaty has a higher level of support than existed at the start of any environmental negotiation process. The problems caused by pandemics are understandable for everyone, and technical solutions are constantly being developed. Since the outbreak of covid-19, many countries have developed relevant national legislation on which future negotiations might draw. The establishment of a financial mechanism to support implementation by developing countries has already entered the discussions.

If precedents are to serve as a guide, the experiences from the environmental field point to a good chance of success-if it was possible to negotiate the existing body of environmental treaties, it should be all the more possible to negotiate a pandemics treaty, given the generally more favourable conditions. In addition, many areas that a prospective treaty is expected to cover, such as access and benefit sharing and One Health, are closely linked to existing environmental regimes. Finally, negotiating a pandemics treaty in the framework of WHO on the initiative of one or more member states is consistent with practice in other areas of international law. Should agreement on a substantive treaty not be immediately achievable, a generally worded treaty constituting a framework for cooperation could be considered as a first step.

\section{Provenance and peer review: Commissioned; externally peer reviewed.}

Competing interests: I have read BMJ policy on competing interests and have the following to declare: none.

This article was written in the framework of a project at the Global Health Centre at the Graduate Institute of International and Development Studies (Geneva) to support the ongoing discussion on a pandemic treaty through independent information on key issues. A policy brief by the same author exploring the issues in more detail is available at www.governingpandemics.org. The information and conclusions stem from the author's participation in treaty negotiations in the areas of environment and public health in various capacities. Katharina Kummer Peiry has over 30 years of experience in international environmental law and policy, including as executive secretary of the Basel Convention, and has published widely in this field. She has also supported the negotiations and subsequent implementation of the WHO Framework Convention on Tobacco Control in different capacities.
WHO. Covid-19 shows why united action is needed for more robust international health architecture. March 2021. www.who.int/news-room/commentaries/detail/op-ed-covid-19-showswhy-united-action-is-needed-for-more-robust-international-health-architecture.

2 International Maritime Organization. Convention on the Prevention of Marine Pollution by Dumping of Wastes and other Matter. www.imo.org/en/OurWork/Environment/Pages/London-ConventionProtocol.aspx

3 International Maritime Organization. International Convention for the Prevention of Pollution from Ships. www.imo.org/en/About/Conventions/Pages/International-Convention-for-the-Preventionof-Pollution-from-Ships-(MARPOL).aspx.

4 Bodansky D. The history of the global climate regime. In: Luterbacher U, Sprinz D, eds. International relations and global climate change. MIT Press, 2001.

5 Egziabher TBG. The Cartagena Protocol on Biosafety: history, content and implementation from a developing country perspective. http://genok.no/wp-content/uploads/2013/04/Chapter-25.pdf.

6 Basel Convention on the Control of Transboundary Movements of Hazardous Wastes and their Disposal (1989). www.basel.int/TheConvention/Overview/tabid/1271/Default.aspx.

7 Kummer K. International management of hazardous wastes: the Basel Convention and related legal rules. Oxford University Press, 1995.

8 The Vienna Convention for the Protection of the Ozone Layer. (1985) and its Montreal Protocol on Substances that Deplete the Ozone Layer (1987). https://ozone.unep.org/treaties/viennaconvention.

9 The FAO Code of Conduct on the Distribution and Use of Pesticides. (1985). www.fao.org/3/y4544e/y4544e00.htm.

10 The UNEP London Guidelines for the Exchange of Information on Chemicals in International Trade. (1987). www.jus.uio.no/Im/unep.chemicals.information.exchange.trade.london.guidelines.1989/doc.html.

11 Rotterdam Convention Rotterdam Convention on the Prior Informed Consent Procedure for Certain Hazardous Chemicals and Pesticides in International Trade. (1998). www.pic.int/TheConvention/Overview/tabid/1044/language/en-US/Default.aspx.

12 Nagoya Protocol on Access to Genetic Resources and the Fair and Equitable Sharing of Benefits Arising from their Utilization (2010). www.cbd.int/abs.

13 Convention on International Trade in Endangered Species of Wild Fauna and Flora. (1973). https://cites.org/eng/disc/what.php.

14 Wijnstekers W. The evolution of CITES. International Council for Game and Wild life Conservation 2011. https://cites.org/sites/default/files/common/resources/Evolution_of_CITES_9.pdf.

15 Secretariat of the Convention on Biological Diversity. Handbook of the Convention on Biological Diversity including its Cartagena Protocol on Biosafety. 3rd Edition. 2007. www.cbd.int/handbook.

16 Ramsar Convention on Wetlands of International Importance Especially as Waterfowl Habitat. (1971). https://jncc.gov.uk/our-work/ramsar-convention.

17 Matthews GVT. The Ramsar Convention on Wetlands: its history and development. 2013. https://leap.unep.org/sites/default/files/2020-09/Matthews-history.pdf.

18 United Nations. United Nations Convention on Desertification. 1994. https://www.unccd.int/sites/default/files/relevant-links/2017-01/UNCCD_Convention_ENG_0.pdf

19 WHO. Environmental health. https://www.who.int/health-topics/environmental-health\#tab=tab__

This is an Open Access article distributed in accordance with the Creative Commons Attribution Non Commercial (CC BY-NC 4.0) license, which permits others to distribute, remix, adapt, build upon this work non-commercially, and license their derivative works on different terms, provided the original work is properly cited and the use is non-commercial. See: http://creativecommons.org/licenses/by$n c / 4.0 \%$. 